\title{
Impact of Financial Risk Management Practices on Islamic Banks Performance in Pakistan
}

\author{
Muhammad Sohaib Ashraf ${ }^{1 *} \quad$ Ahmad Shukri Yazid $^{2} \quad$ Norizan Binti Remli $^{2}$ \\ 1.PhD Scholar, Faculty of Business and Management Sciences, Universiti Sultan Zainal Abidin, 21300 Kuala \\ Nerus, Terengganu, Malaysia \\ 2.Professor, Faculty of Business and Management Sciences, Universiti Sultan Zainal Abidin, 21300 Kuala \\ Nerus, Terengganu, Malaysia
}

\begin{abstract}
:
In current era, an effective risk management process is the basic requirement to perform better financial performances. Once the risk has been recognized, then organizing the risk is one of the main objectives to be done. The relationship between risk and return is associated with each other. In Islamic finance, reward cannot be obtained without risks i.e., more risks more rewards and vice versa. The key objective of the current study is to investigate the impact of the financial risk management practices (RMPs) on the Islamic banks (IBs) financial performance in Pakistan. To achieve the main objectives, this research measures the existing RMPs of the IBs and associate these RMPs with the IBs financial performance. This is a dynamic study that has researched both primary and secondary data. To proxy the IBs financial performance, return on assets (ROA) stood average for six years (2014-2019). An adapted questionnaire is distributing among the IBs risk managers for measuring the financial risk management practices of IBs. The methodology of this study comprises on the analysis of data using the analysis of multiple regression and correlation analysis. The results are display in tabulated form and mathematical regression equations. The current study identifies that practices of IBs in Pakistan indicates better financial risk management, resultantly these RMPs discloses the optimistic relationship with IBs financial performance. The study on financial performance recommends that IBs should plan and attempt the advanced techniques and process of risk measurement in IBs. To mitigate the financial risk, the current study proposes to trained the IBs managers with modern techniques which will be very useful and valuable for the IBs financial performance.
\end{abstract}

Keywords: Risk Management, Islamic Banks, Financial Risk, Financial Performance

DOI: $10.7176 /$ RJFA/12-14-02

Publication date:July $31^{\text {st }} 2021$

\section{Introduction}

\subsection{Background}

From the last two decades, FRM is more significant. The globalization is in the dynamic form in the development of capital market and in the meantime the rise of the volatility which produced doubt at corporate division. Financial performance and capital structure of the institutions are influenced with high extent by unusual volatility in global financial markets producing the expansion of financial management, which emphasizes on the key variables expressing the cause of risk, foreign exchange, commodity and equity Brezeanu et al. (2011).

Financial risk is used for several kind of risks related with financial dealings that contain organizations loans in the risks of avoidance. The relationship between profitability with financial risks, efficiency and capitalization is very strong. Ariffin. N. M and Kassim. S. (2011), express that in the financial transactions, as a result of financial variables activities the financial risks (FR) occur from potential losses. These losses related with risks due to the liabilities which are not in match with assets. In the present study the researcher emphasis the financial term i.e. financial risks which enclosed the other type of risks such as market risk, credit risk, liquidity risks, foreign exchange risk etc. The basis of financial risk is due to the fluctuations in interest rates, market prices variations, default risk, the gap of liquidity which influence the cash flows, so as a result the better financial performance in financial market. In Pakistan, IBs faces highest categories of financial risks, for instance liquidity risk, credit risk, market risk, operational risk and foreign exchange risk.

According to Markowitz H. (1959), the financial term FRM can also be well-defined as a set of financial practices which decreasing the costs related with the cash flow instability and increases the bank performance. The attitude of risk manager and the corporate governance $(\mathrm{CG})$ can be influencing the RM practices.

Efficiency and risk management are basic requirements for measuring risk management efficiency of banks as a decision-making unit (DMU). Despite increasing global market uncertainties, both strategic and operational practices need risk management efficiency measurements to achieve efficiency levels (Zakaria, S., and Islam, S. ,2019).

A strong RM practices can assist the IBs to decrease their disclosure to risks and increase their capability to 
enter in the financial market. As compared to the conventional banks CBs, IBs have more risks and FRM is the key performance indicator in IBs operations. After the global financial crises GFC in 2007 - 2009, which directly influence the world financial economy has strengthened the basic requirement to consider the several techniques that implemented in banking to assessing its activities. It is essential to acquire a broad point of view of main indicators that affect the banking activities as well as business models capability connected with risk. Therefore, a question is raised that how this capability is control bank's inner and outer side by governance procedure. That fact must be considered that, the procedure of sensitivity analysis and correct benchmarks to measure the banks actual adequacy should be considered for competing the difficult market situations and due to the financial strategy bears the risks and consecutive shocks (Basel Committee on Banking Supervision ,2001).

The risk of bankruptcy will occur in IBs when it fails to fulfils the short term and long term financial responsibilities. The risk of bankruptcy expresses the financial performance of banks. When the bankruptcy risk will higher, the financial position will be going towards weakness (Fakhrunnas, F., \& Imron, M. A., 2019).

\subsubsection{Financial Risk Management}

There are various categories of risks, which arises in business. First, there is a need to distinguish among business risks and financial risks. In business risks, it arises from the nature of the business firms and due to the financial fluctuations in variables while the financial risks arise in financial market from potential losses (Philippe J., \& Joseph, K. S. ,1996). Financial risk is related to the factors that affect the financial market. In financial risk, it can be divided into two parts i.e. credit risk and market risk.

According to the Basel committee, financial RM can be defining in four development phases, (i) first is the identification of credit, market, operational and other risks, (ii) secondly by the risk model and data to assess the risks, (iii) thirdly for timely basis assessment of risks by monitoring and reporting and, (iv) finally from the top management, the benchmark of these related risks. In the banking institutions, due to the variety of the risks no guidelines and instructions recommended for comprehensive RM procedures. In this regards every financial institution is independent for RM techniques. Although in modern market economy there is requirement of banking regulations. Primarily the vital efforts are the identification of risk and then assess to recognize the effect on profitability of the banking institutions. For gaining the prescribed purpose, several kinds of procedures can be used starting from simple to practical models. There is limitation to measuring the risks controlling and risks monitoring in financial institutions. Financial institutions can regularly measure the risks and make ensure the accuracy. The best RM procedures measure risks of financial assets and specific transactions. Afterward determining the risks, the financial institution can transfer risks limits by standardize procedures and policies which express authority and responsibility. The financial institutions can use these risk limits as a medium to control the associated risks with its practice.

Voinea, G., and Sorin,G.A. (2009) stated that in the beginnings of 1990, FRM got the high-level status due to the growing of financial market volatility of financial institutions, financial products and financial derivatives. The procedure of RM has used to improve the tradeoff for risk and reward, and it does not understand to reduce the risk. So, the basic responsibility of Risk Management procedure has made sure for a financial institution that it does not involve in any needless risk-based business. Various companies such as WorldCom, Enron etc bear financial losses due to the lack of RM procedure. Similarly, Ariffin. N. M and Kassim. S. (2009) expressed that Islamic banks RM has played a vital role in financial transactions. Like conventional financial institutions, IB exhibit specific nature of financial intermediaries, depositary intermediaries and investment intermediaries etc. Although, according to the Shariah guideline and procedure there are some major differences. Yazid et al. (2011) stated that the basic decision of application of RM in the control of topmost administration such as board of directors. It is also essential to mention that in RM program resources needed approval.

According to Iqbal et.al. (1998), based on the assets structure model, two models exist in IBs. First model is known as two-tier Mudarabah model. This model is comparable to the CB interest-based profit-sharing model. So, this Islamic model replaces interest-based model by modes of profit sharing (PS) on both balance sheet items i.e. banks assets and liability. The prescribed model in IBs has not only played a role of commercial bank but also played a role of investment intermediary. Another IB model is one-tier Mudarabah model with combination of various investment techniques. Due to the facing operational and practical issues by using PS modes on assets side of balance sheet, this model is in early stages. Therefore, they chose for fixed income financing modes.

1.1.2 Financial Performance (FP)

Financial performance (FP) is the name of assessing banks operations and policy in financial form. In banking system, financial performance indicates the bank's comprehensive financial strength from time to time. FP also supports to analyze the various banks across the banking institutions at the same time. Toutou, J., \& Xiaodong, X. (2011) defined the financial performance as an overall assessment that how a bank from its capital produces revenue.

Suka, J. N. (2011) stated that the financial performance is a subject measure of how sound a firm generates revenue from its business capitals. Many indicators are used to measure the financial performance of banks, the most important of which are return on assets denoted by ROA, second is return on equity denoted by ROE and 
third is adjusted return on capital denoted by RAROC. ROA i.e. product profit margin is the net income, it is also called total asset turn over. ROA is derived by dividing the net income of the company by average total assets. ROA and ROE figures are equal if there is no debt on any company. The purpose of ROA is to measures that after tax how a bank generates revenue for each rupee in assets of the company. ROA is an ordinary measure of organizational performance (Ross et al., 2008). According to Van Horne and Wachowicz (2005) ROA after the expenses and tax, indicates the profitability of a company on its assets. Islam and Salim (2011) expresses that ROA is the most rigorous and extreme assessment of return to shareholders.

The formula of ROA is as follows:

ROA $=$

Net Income

Average Total Assets

The most standard measure is return on equity (ROE), is an internal financial perfor mance for measuring the shareholder value. It reflects that how bank administration effectively using shareholders' reserves. It also recommends a direct measurement of financial return of shareholders' financing. It is available for analyst and it relies solely on public information and at the same time, it is important to compare different companies. The following formula means that the better the equity return, the better the more efficient the administration in using shareholders' financing.

According to Van Horne (2005) ROE indicates the profitability to shareholders of a company after total taxes and expenses. ROE is from time to time disintegrated into distinct drivers called the DuPont analysis, which used to assess the firm components to evaluate the component segments of a business's ROE. This ratio also permits a depositor and shareholder to determine what financial practices are paying the most to the changes in ROE. The above procedure for performance has been followed by IBs also.

The formula of ROE is as follows:

\section{ROE $=$ \\ Net Income \\ Average Total Equity}

\subsubsection{Influence of Financial Risk Management on Islamic Financial Performance}

Efficient and effective FRM is the basic requirement of any financial institution because risk and return are interrelated with each other, as risk increases resultantly return increases. In $\mathrm{CBs}$, financial risk arises due to the fluctuations in currency exchange rates, interest rates and effects of poor liquidity management. Bikker, J. A., \& Metzemakers, P. A. (2005) express that in financial institutions, performance and profitability depends upon the institutions ability to forecast, oversee and avoid risks and provision possibility to cover losses. According to Shafiq A. and Nasr M. (2010) the banking institutions identifies that an organization required not do trading in a way that implicates risks upon it and nor should he take the risk that can be effectively passed on to the other parties. The banks must manage the risks at a solid level, either through the financial market itself or through its owners in their own portfolio. These institutions should only accept risks that are part of the bank's services.

\subsubsection{Islamic Banks in Pakistan}

Islamic commercial banks are also working as financial intermediary institutions in Pakistan. These institutions take deposit from the clients and works as mudarib and as partner under the Shariah guidelines and instructions. According to the SBP, March 2020 annual report, a huge network of IBs has been working in Pakistan. In this network there are twenty-two (22) Islamic financial institutions in which five (5) IBs are full-fledged while remaining seventeen (17) working CBs Islamic windows. By end of March 2020 there are 3,250 branches in 120 districts. The total branches of CBs as Islamic windows are 1,375. To mitigate cyber-attack risk, every IBs and Islamic banking window doing effort from safety point of view and they are creating awareness to their clients (SBP, 2020).

\subsection{Research Problem}

The robust banks are rewarded due to the sound risk management and better performance, whereas weak banks are faced high cost of capital raising. To organize the banks risks, the discipline of financial market provides encouragement carefully and to activate effectively (Srairi, S. ,2019).A study conducted by Rehman, A. et. al., (2018) and expressed that there is harmony existed for many years among practitioners, regulators, policy makers and academia that efficient RM is essential to the achievement of advanced banking, interest based banks or Islamic banks. The researcher stated that this study covers all the phases of bank RMP plus those evolving after GFC (global financial crises) for instance governance. This reason empowers us to categories the zones that take part to weak RMPs in surveyed banks.

IBs implement various techniques of RMPs. Due to the asset category and liability structure in IBs, it is not only risky like $\mathrm{CBs}$, but IBs has its unique risk status due to its unique products. So, it is significant to research 
how IBs are handling and supervising the financial risks. In the present study, it examines the effects of IBs financial risk management practices on the performance of IBs in Pakistan. The key concentration of this study is only some components of risk management. Limited studies have been done in Pakistan to found what is impact of financial RM practices and its impact on IB performance.

\subsection{Research Objective}

The primary objective of this study is to investigate the impact of financial risk management practices on IBs financial performance in Pakistan. The secondary study objective is to examine the relationship strength between financial RM practices and IBs financial performance.

\subsection{Contribution}

The contribution of this study is the advancement of the vital subject of Islamic FRM. Categorically, the current research will express extent to which the financial risk model is used by IB in Pakistan. This study will be very supportive to regulators and policy makers to propose and plan specific program and policies. This will also explain the effective strategy used by various IBs to manage the financial risks. The current analysis will also helpful for other Islamic financial institutions. They can adopt advanced procedures of risk management and resultantly which will enhance the performance of that institution. According to the academician's point of view, the current study contributes as the significant information in the existing body of the knowledge. The findings of the current research will also helpful for SBP in order to framing the instructions and guidelines which improve the financial RM in IBs division.

\section{Literature Review}

In Islamic finance there are products-based banking system in which Islamic bankers generate economy of the country. These banks play a role of creditors as well as investors. Western banking sell Islamic banking products through Islamic window and IBs also performs under guidelines of the Basel II accord. Resultantly these financial institutions are facing issues of emerging inside models for the betterment of measurement, monitor and organize the main kinds of financial risks such as operational, credit and market risks. It is very difficult for IBs to distinguish and estimate the nature and existing risks transformation among the risk's classes (Akkizidis, \& Khandelwal, 2007).

A study conducted by Ariffin and Kassim (2009) indicates the association between RMP and IBP in Malaysia. The study expresses the activities of daily RMP and IBs financial performance. By using the data both from primary sources (questionnaire) and secondary sources (Financial annual reports of IBs), the study results highlighted that there is need of some strategy to make more strengthen the RMP in IBs. Amin et al (2014) express that the financial performance of banks can be measure from the return on equity and return on investment (ROA \& ROE) whereas financial risk can be calculated to take the average of financial risk. IBs also works for the profitability in corporate sector so profitability is the name of performance of the banks and generally calculated in the ratios methods (Ruziqa, A. 2013). The researcher found that in the case of US bankruptcy in 2009, return on assets (ROA) is one of the momentous bank's performance element according to the forecasting point of view. The failure of financial performance shows the financial risk of banks and the financial risk is the result of losing of profit, which is based on banks attributes.

Islamic financial Institutions guidelines and instructions has been derived from the Shariah which is the combination of Holy Quran and Sunnah. Consequently, in IB, there is complete restriction on any non-Islamic, unethical and illegal transactions and activities. As stated in Holy Quran "O you believe! Wine and gambling, altars and divining are filth, made up by Satan, therefore refrain from it, so that you may be successful (Taqi,2000). There is a need to differentiate between pure risk and that practices of business uncertainties which contain risk taking and an element of chance involvement. All kind of risks taking in not completely restricted in IB transaction. Anyone who bears and face all kind of risks in his life, are not the identical type of risks. Wanjohi et al. (2017) examined a study on the effects of financial RM and Kenyan commercial banks performance. The results of the study present a positive significance performance.

To measure the degree of RM practices and its application, a study conducted by Hassan, A. (2009), on RM practices of IBs in Brunei Darussalm. This study indicates that the use of different methods, which deal with different risks, the result shows that just like the CB System, different types of risks are being used within the Islamic Banking System due to its uniqueness. This is the result of the products being presented within the Commission. Rashid, A., and Jabeen, S. (2016) stated that during 2006-2012 study on performance determinants in which an unbalanced annual panel data used. The regression result illustrated that operating reserves and overheads, efficiency are significant determinants of CBs performance, however, deposits and concentration, operating efficiency are significant in expressing the performance of IBs. It also displays that the influence of lending interest rate and GDP the on performance is negative for CBs and IBs may emphasis on regulating operating costs and overheads to recover performance as, according the experiential outcomes presented in the 
study, both of these variables are negatively related to the FPI. Therefore the final results propose that developments in complete regulatory practices and new values and criteria in financial risk management and operating efficiency are necessary to increase IBs performance.

For many years, consensus existed between academics, practitioners and regulators that effective risk management is pivotal to the success of modern banks, conventional or Islamic. Using structured questionnaire, this study captures all aspects of bank risk management practices including those emerging after the financial crisis, such as governance. This enables us to identify areas that directly contribute to weak risk management practices in the banks surveyed.

\subsection{Financial Risk Management Doctrine}

\subsubsection{Theory of Moral Hazard}

In moral hazard theory there is a risk in which one party puts the other party own interests first, but the first party's decision-making has a greater impact on the other party. Such risks have a direct impact on the financial system. According to Krugman, P. (2009) that if one person decides how much risk to take but the other party bears it because if things go wrong then the financial cost will also have to be borne. Weil J. (2012) stated that financial management is a standard and a criterion which privatizing the gain plus benefits and socializing damages. The performance of financial engineering with alternate risk delivered and organized finance, destructive accounting, enormous leverage, suspicious rating of credit has allowed their professionals to excerpt the worth on high level, to run away with money during unrestricted from the CG, risk management, and financial regulation, all this was practically useless.

\subsection{Islamic Banking Financial Performance Determinants}

In the Islamic financial industry world, there have been several studies conducted regarding the banking performance determinants. Various studies were indicated the results of developed countries whereas fewer studies were conducted in the developing countries. Most of the researchers have conducted the studies on the determinants of the performance of banks for instance Abreu and Mendes (2002), Demirguc-Kunt and Huizinga (1999), Athanasoglou et al. (2006), Pasiouras and Kosmidou (2007). A study on the banking determinants examined by Ahmed and Khababa (1999) in the Kingdom of Saudi banks and ROA, ROE plus EPS (earnings per share) \% were used as a profitability. The conclusion of the said analysis expresses that main factors of banks performance in Saudi Arabia bank size and business risk. Normally, performance is a level of possibility to programed business goals and targets. Performance is the end outcome as well as qualitative and quantitative measurement of endeavors to attain the target.

Zeitun, R. (2012) sated that in the world of Islamic banking industry, there is no any single case of insolvency while on the conventional banking side there were 100 bankruptcy cases which was involving interest based activities in the USA and in other remaining countries got insolvent due to the financial crises. The researcher has used two performance measures for determinants of IB, which is very popular in finance i.e. ROA. A sample of Pakistani IBs has been conducted to examine the impact of specific banks factors on the bank's performance by using multivariate regression models for the period 2006-2009. The researcher found that there is a significant positive effect of capital adequacy and gearing ratios on IBs performance and also concluded that impact of IBs size on the IBs performance has negatively with insignificantly way. (Akhtar et al. ,2011)

\section{Research Methodology}

The current study will be conducted in two analysis stages for accomplishing the research objectives. Primarily, to know and measure the present level of financial RM practices in IBs, the researcher distributed the survey questionnaire. For financial RM practices in IBs, a score is given to every IB and after achieving the score this will be analyze with the mean score of every category of risk managements practices. The criteria are classifying in five kinds i.e. risk environment, measurement, mitigation, monitor and internal control of risk methods. For the analysis of IBs performance, secondary data from annual reports has been used from authorized web sites, annual financial reports. Secondary data provides ROA of full-fledge IBs. Correlation analysis technique will be used to achieve the secondary objective of the study which is the relationship strength between RMP and IBs performance.

According to Ostle and Malone (1988), to measure the durability of the relationship, the technique of correlation has been used. Newbold et al., (2007) stated that the coefficient of sample correlation analysis provides a systematize measure of the linear relationship among two variables. The investigation of correlation is calculated for all variables. Based on the descriptive statistics with frequency distributions, IBs financial performance will be analyze. In the second stage of analysis of variables, audited financial annual reports has been taken from the authorized financial web sites. Therefor the variables of the current study such as performance, profitability (ROA) are calculated in ratio. 


\subsection{Research design}

The research design of the current study comprised on descriptive. According to Bikker and Metzemakers (2005), the descriptive research design presents a precise outline of events, individuals for instance abilities, behavior, beliefs, opinions, and knowledge of a specific individual, group or situation. The research design of current study is contained on both primary and secondary data. In primary data the researcher adapted a structured questionnaire (Ariffin and Kassim ,2011) and (Khan and Ahmed ,2001) for determining the impact of financial RM practices on financial performance and secondary data is taken from the IBs annual financial reports for determining the strength between them.

\subsection{Population and Sampling}

In the current study, the target population is $22 \mathrm{IBs}$ in Pakistan. The sample of the current study are Islamic banks. So questionnaire was distributed among risk managers working in operations, credit department and RM department of IBs in Pakistan. The study is limited to IBs of Islamabad capital territory (ICT) the federal area of Pakistan. Overall 58 IBs branches with CBs Islamic windows has been operating in Islamabad. The data collection from all staff is not possible so proportionate sampling technique has adopted. The formula which used for the proportionate sampling is given as

$$
\underset{N}{n \boldsymbol{k}}=\boldsymbol{n}(\underline{\boldsymbol{N k}}) \quad \text { (Chaudhry, S.M., \& Kamal, S., 2001) }
$$

Where

$n=$ number of branches of each bank

$\mathrm{N}=$ number of branches

$n k=$ Proportion of Sample in $\mathrm{k}^{\text {th }}$ banks

$\mathrm{Nk}=$ number of respondents

\section{Table 1: Sample selection}

Indicator

\subsection{Variables of the Study}

The given variables are used in this study.

1. Risk Management Environment (RME)

2. Risk Measurement (RMe)

3. Risk Mitigation (RMt)

4. Risk Monitoring (RMo)

5. Internal Control (IC)

6. Return on Assets (ROA)

\subsection{Data Collection}

Due to two key reasons, the primary data has employed. First, the limitation of time because the primary data is collected easily which supports to conclude the study within due time. The second cause is that the annual report has made on real performance so there is no chance of fabricated information (Muhammad, 2019).

As discussed in above section that this study comprised both data i.e. primary plus secondary, so the questionnaire techniques is used as a primary data. For the collection of data, an adapted questionnaire has been used and there were six sections in questionnaire as tabulated in Table 2

Table 2: List of questionnaire sections in adapted study

\begin{tabular}{|c|l|c|}
\hline Serial No. & \multicolumn{1}{|c|}{ Section } & Questions \\
\hline 1 & Demographic Information & 6 \\
\hline 2 & Risk Management Environment & 10 \\
\hline 3 & Risk Measurement & 4 \\
\hline 4 & Risk Mitigation & 6 \\
\hline 5 & Risk Monitoring & 4 \\
\hline 6 & Internal Control & 5 \\
\hline
\end{tabular}


The primary section of the questionnaire was arranged to collect IBs risk manager awareness and IB information. The secondary section was arranged for environment of RM regarding RMPs in IBs. The next section of RMP questionnaire was planned to collect RM information regarding measure the risk which tracked by risk monitoring, mitigation and techniques of internal control in IBs. The RM questionnaire was comprised five (5) point Likert scale. Which means started from strongly agree i.e. 5 to strongly disagree i.e. 1. It means that five (5) for strongly agree and four (4) for agree likewise three (3) for neutral or no option, two (2) for disagree and one (1) is for strongly disagree. The questionnaire survey was sent to the mangers of RM department, credit department, and operations in 22 IBs in Pakistan to measure the RMPs of designated IBs. In questionnaire only IBs risk managers are required to respond. The primary data has been taken for the independent variable i.e. RMP. As for as the secondary data for the dependent variable i.e. IBs performance related, it has taken from the annual financial reports of IBs and CBs Islamic windows. In Pakistan the total no of full fledge IBs are five (5) while IBs windows of CBs are contained seventeen (17) so total IBs are twentytwo (22). Therefor the choice twenty IBs is depends upon on accessibility of data six years from 2014 to 2019 for measuring financial performance.

First, the list of five full fledge IBs are as follows

Table 3: List of full fledge Islamic Banks (Federal Area) Source: State Bank of Pakistan, 2020)

\begin{tabular}{|l|l|l|l|}
\hline Name & Name & No. of Braches & Respondents \\
\hline 1 & Al Baraka Bank (Pakistan) Limited & 2 & 6 \\
\hline 2 & Bank Islami Pakistan Limited & 3 & 9 \\
\hline 3 & Dubai Islamic Bank Pakistan Limited & 2 & 6 \\
\hline 4 & Meezan Bank Limited & 11 & 33 \\
\hline 5 & MCB Islamic Bank Limited & 3 & 9 \\
\hline & Total & $\mathbf{2 1}$ & $\mathbf{6 3}$ \\
\hline
\end{tabular}

Table 4: List of Islamic banking windows of CBs are as follows

\begin{tabular}{|l|l|l|l|}
\hline Name & Name & No. of Braches & Respondents \\
\hline 1 & Allied Bank Limited & 2 & 6 \\
\hline 2 & Askari Bank Limited & 3 & 9 \\
\hline 3 & Bank Al Habib Limited & 2 & 6 \\
\hline 4 & Bank Alfalah Limited & 3 & 9 \\
\hline 5 & Faysal Bank Limited & 2 & 6 \\
\hline 6 & Habib Bank Limited & 4 & 12 \\
\hline 7 & Habib Metropolitan Bank Limited & 2 & 6 \\
\hline 8 & National Bank of Pakistan & 4 & 12 \\
\hline 9 & Silk Bank Limited & 2 & 6 \\
\hline 10 & Sindh Bank Limited & 1 & 3 \\
\hline 11 & Soneri Bank Limited & 2 & 6 \\
\hline 12 & Standard Chartered Bank (Pakistan) Limited & 3 \\
\hline 13 & Summit Bank Limited & 1 & 3 \\
\hline 14 & The Bank of Khyber & 1 & 3 \\
\hline 15 & The Bank of Punjab & 4 & 12 \\
\hline 16 & United Bank Limited & 2 & 6 \\
\hline 17 & Zarai Taraqiati Bank Limited & 1 & 3 \\
\hline & Total & $\mathbf{3 7}$ & 111 \\
\hline & Grand Total & $\mathbf{5 8}$ & $\mathbf{1 7 4}$ \\
\hline
\end{tabular}

\subsection{Data Analysis}

The data analysis part of study is very critical. To investigate the influence of financial RMP on IBs performance, inferential statistics is used in this study. To determine the significance of every regression, the t-test was implemented. An inferential statistics F-test was applied to measure that how independent variable (IV) as a cluster express fluctuation in the dependent variable (DV).

\subsection{Measurement of Model}

For this study we used, regression analysis in the form of equation. This model provides statistical techniques estimation between financial RM and financial performance.

Where as

$$
\mathrm{Y}=\mathrm{a}+\mathrm{b}_{1} \mathrm{X}_{1}+\mathrm{X}_{2} \mathrm{~b}_{2}+\mathrm{X}_{3} \mathrm{~b}_{3}+\mathrm{X}_{4} \mathrm{~b}_{4}+\mathrm{X}_{5} \mathrm{~b}_{5}+\varepsilon
$$


$\mathrm{a}=\mathrm{A}$ constant. It is the point of interception of regression line.

$\mathrm{Y}=$ Financial performance of Islamic banks which is measure by the average of return on assets (ROA) for six years (2014-2019). $b_{1}, b_{2}, b_{3}, b_{4}, b_{5}$ are the coefficients which have to be determined. $X_{1}, X_{2}, X_{3}, X_{4}, X_{5}$, are the indicator of independent variables. These variables can be measured by the questions in the Questionnaire Performa.

Where:

$\mathrm{X}_{1}=$ Risk environment $\mathrm{X}_{2}=$ Risk measurement, $\mathrm{X}_{3}=$ Risk mitigation, $\mathrm{X}_{4}=$ Risk monitoring, $\mathrm{X}_{5}=$ Internal Control, $\varepsilon$ $=$ Error term or disturbance term

To operate and measure the financial RM practices, 5 (five) key factors in reference BCBS (1999) were taken to plan a questionnaire. The key factors of RM practices are RM environment, measurement, mitigation, monitoring and Internal Control. After that the mean of the variables associated with the mean value of ROA of IBs for the duration of six (6) years i.e. 2014-2019.

Table 5: Measurement of Study Variables

\begin{tabular}{|c|c|}
\hline Variables & Measurements \\
\hline $\begin{array}{l}\text { Return } \\
\text { Assets }\end{array}$ & $\begin{array}{l}\text { ROA is financial ratio which can be calculated using the formula. ROA for six years was } \\
\text { used. }\end{array}$ \\
\hline $\begin{array}{l}\mathrm{RM} \\
\text { Environment }\end{array}$ & $\begin{array}{l}\text { RME depends upon on various parameters which can be found by Likert scale. In this } \\
\text { section, there are different types of questions by adding them we can get score } 100 \% \text {. }\end{array}$ \\
\hline $\begin{array}{l}\text { Risk } \\
\text { Measurement }\end{array}$ & $\begin{array}{l}\text { Risk Measurement is quantity type measurement which can be found by Likert scale. In this } \\
\text { section, there are different types of questions by adding them we can get score } 100 \% \text {. }\end{array}$ \\
\hline Risk Mitigation & $\begin{array}{l}\text { Risk mitigating is quantity type measurement which can be found by Likert scale. In this } \\
\text { section, there are different types of questions by adding them we can get score } 100 \% \text {. }\end{array}$ \\
\hline $\begin{array}{l}\text { Risk } \\
\text { Monitoring }\end{array}$ & $\begin{array}{l}\text { Risk monitoring is quantity type measurement which can be found by Likert scale. In this } \\
\text { section, there are different types of questions by adding them we can get score } 100 \% \text {. The } \\
\text { outcome of the index shows the collectively RM status of IBs. }\end{array}$ \\
\hline Internal Control & $\begin{array}{l}\text { Internal control is quantity type measurement which can be found by Likert scale. In this } \\
\text { section, there are different types of questions by adding them we can get score } 100 \% \text {. The } \\
\text { outcome of the index shows the collectively RM status of IBs }\end{array}$ \\
\hline
\end{tabular}

\section{Analysis of Data}

\subsection{Financial Risk Management Practices in IBs Pakistan}

In order to find the FRM of IBs, the descriptive analysis was used with the help of 5-lickert scale method. The highest score in the Likert scale shows that the informants of the questionnaire are on agreement in order the adoption of IBs, FRM has further divided into five parts i.e.RM environment, risk measurement, risk mitigation risk monitoring and Internal Control.

All the above practices have advised by Basel Committee (1999).

\section{(i) Risk Management Environment}

The result of the questionnaire shows that the informants agreed on all the items statements. The large no. of the informants scores more than 4.1 agreed on the above items. There is separate department in the IB, which is the accountable for RM. IBs has their own policies and guidelines under the Shariah governance. Generally, the outlines of risk have approved by the board of directors. In IBs, there is a separate branch which is responsible for the $\mathrm{r}$ monitoring of risk, identifying and supervisory the items. The minor risk cases have been solved on regional level while the major risk cases have been transferred to the head office of banks.

\section{(ii) Risk Measurement}

The mean score of the three items statements is more than 3.6 and the informants are an agreement that the measurement of risk techniques is better but there is a room for improvement. Many informants know the measurement of risk techniques however there is a need and hard work to improve the risk efficiency. There is need of advanced techniques on strongly basis. In IBs the products type and nature is unique so the risk ratio has increased, so there is a requirement of modern software and tools techniques for risk measurement.

\section{(iii) Risk Mitigation}

Majority of the informants mean score lies between 3.7-4.1 which shows credibility of risk mitigation, however in forward sales of IBs there are some issues which cannot be include in risk mitigation technique survey questionnaire. In this area, further improvements within risk mitigation are needed to effectively manage risks

\section{(iv) Risk Monitoring}

Majority of the IBs issues annual financial reports based on quarterly, semiannually and annually which contain all the information's regarding monitoring of risk. In the data analysis of monitoring of risk, the results of mean score are in between 3.6 and 4.5 which seems a better score.

During the financial year from 2014-2019, the mean ratio of ROA is given as follow in the Table 3 . 


\section{(v) Internal Control}

Majority of the respondents strongly agreed in all items. In Pakistan, the RM practices in IBs are going towards better position. The practice of internal control in IBs obtained the better mean score i.e. $77 \%$ followed by RM environment practices while risk monitoring presented a mean of $65 \%$ and practices of risk mitigation achieved a mean of $71 \%$. Although practices of risk measurement computed a mean less than others measures such as $63 \%$.

\subsection{Regression Model}

$$
\mathbf{Y}=\mathbf{a}+\mathbf{b}_{1} \mathbf{X}_{1}+\mathbf{X}_{2} \mathbf{b}_{2}+\mathbf{X}_{3} \mathbf{b}_{3}+\mathbf{X}_{4} \mathbf{b}_{4}+\mathbf{X}_{5} \mathbf{b}_{5}+\varepsilon
$$

where $\mathrm{a}=\mathrm{A}$ constant. It is the point of interception of regression line.

$\mathrm{Y}=$ Financial performance of Islamic banks which is measure by the average of return on assets (ROA) for six years (2014-2019) $b_{1}, b_{2}, b_{3}, b_{4}, b_{5}$ are the coefficients which have to be determined.

$\mathrm{X}_{1}, \mathrm{X}_{2}, \mathrm{X}_{3}, \mathrm{X}_{4}, \mathrm{X}_{5}$, are the indicator of independent variables. These variables can be measured by the questions in the Questionnaire Performa.

Where:

$\mathrm{X}_{1}=$ Risk environment, $\mathrm{X}_{2}=$ Risk measurement, $\mathrm{X}_{3}=$ Risk mitigation, $\mathrm{X}_{4}=$ Risk monitoring, $\mathrm{X}_{5}=$ Internal Control, $\varepsilon$ $=$ Error term or disturbance term

T-test shows that is highly depend on financial RM. The above model shows that financial performance will highly depend on financial risk management

From the given data in table 6 , the regression model has arisen and presented in the given form of equation; $\mathrm{Y}=0.051+0.079+0.071+0.044+0.075-0.243$

Table 6: Regression Coefficients

\begin{tabular}{|c|c|c|c|c|c|}
\hline \multirow[t]{2}{*}{ Model } & \multicolumn{2}{|c|}{ Unstandardized coefficient } & \multicolumn{2}{|c|}{ Unstandardized coefficient } & \multirow[t]{2}{*}{ Sig } \\
\hline & $\mathbf{B}$ & Std. Error & & $\mathbf{T}$ & \\
\hline 1 (Constant) & -.243 & .022 & & -9.593 & 0 \\
\hline RM environment & .051 & .023 & .121 & 2.372 & 0.026 \\
\hline RMe (measurement) & .079 & .016 & .390 & 4.917 & 0.015 \\
\hline RMi (mitigation) & .071 & .015 & .385 & 4.844 & 0.019 \\
\hline RMo (monitoring) & .044 & .017 & .183 & 3.152 & 0.011 \\
\hline Internal Control & .075 & .027 & .214 & 3.159 & 0.017 \\
\hline
\end{tabular}

a. Dependent Variable: Average (ROA, 2014-2019)

The above research model indicated that IBs financial performance is significantly dependent on financial RM practices levels. The t-test shows that the IBs performance is expressively dependent risk mitigation practices and risk measurement.

\section{Explanation of Findings}

The explanation of current study stated that a strong positive association among financial RM and performance of IBs. It is also found that correlation between risk mitigation and ROA is positively significant i.e. $+77 \%$. Similarly, the correlation between risk measurement and ROA is $71 \%$ while there is moderate correlation between return on assets and internal control, RM environment, risk monitoring (49\%, 45\% and $43 \%$ ) respectively. The result of the correlation showed that increases in ROA is due to the increase in risk mitigation. Regression coefficients analysis showed that intercept value is negative i.e. -0.243 . R square presented $74 \%$ of ROA is explained by financial RM practices. Similarly, the adjusted R Square also indicated the same. The above results showed the strong influence between financial RM practices and IBs performance. According to the above table 3 , it showed that one-unit increase in RM environment index will cause 0.051 raises in ROA. An increase of one unit in index of risk measurement will lead to 0.079 rise in ROA. Similarly, an increase of one unit in index of risk mitigation and risk monitoring will lead to 0.071 and 0.044 rise in ROA respectively. Also an increase of one unit in index of internal control will lead to 0.075 . Al the above outcomes showed a positive significance.

\section{Summary}

\subsection{Findings}

The present study shows that there is a closed relationship between financial RM and financial performance of IBs in Pakistan. Similarly, ROA and measurement of risk correlation is significantly positive i.e. $77 \%$. Based on all calculations it has been derived that there is direct proportionality between ROA and mitigation of risk. Adjusted $\mathrm{R}^{2}$ confirms that there is close association between financial RM practices and financial performance of 
IBs in Pakistan. In addition, the outcomes indicate that financial RM efficiency positively influenced on performance of IBs. In the analysis, the coefficients present that negative value of interception.

\subsection{Conclusion}

This is the first study, which used both data i.e. primary plus secondary data to determine the impact of financial RMPs on Islamic banking performance in Pakistan. In the questionnaire, the section regarding board of directors (BoD) polices and Shariah governance structure indicates that general polices has been approved by BoD and it shows that the administration takes obligatory action to organize and control the risk. Furthermore, this study also intentions to deliver the connection and association between financial risk management practices and its impact on IBs performance by using the correlation analysis the data analysis showed that financial RM has great effect on financial performance and resultantly the practice of mitigation of risk followed it. Islamic banks also used better tools and techniques of risk mitigation but there is need of more advance techniques of risk management. Hence, when the investment started in Islamic banks with RM practices and risk mitigation tools and techniques, consequently the revenue and income generation also increases and IBs going towards better performance and strengthen the relationship.

\subsection{Recommendations}

Although the practices of RM in IBs are better than CBs RM practices, but there is a need to improve the RM methods with more advanced techniques. As discussed in this study that in IBs the system of RM is more efficient, but also riskier due to the new and unique products in its nature, resultantly there is a requirement risk mitigation of Shariah compliant in order to retain their attractiveness in the Islamic financial markets. Due to the adoption of different advance techniques, the revenue of IBs increases and performance also increases. Further research is needed on the RM practices with the moderating role of the board of directors and Shariah governance attributes as a new variable. The questionnaire of the study should in detailed and also add the Shariah guidelines regarding Shariah governance characteristics and IB performance in Pakistan.

\section{References}

Ahmed, A. M., \& Khababa, N. (1999). "Performance of the banking sector in Saudi Arabia". Journal of Financial Management \& Analysis, 12(2), 30.

Ariffin, N. M., \& Kassim, S. H. (2011, December). "Risk management practices and financial performance of Islamic banks: Malaysian evidence". In 8th International Conference on Islamic Economics and Finance (pp. 19-21).

Ariffin. N. M and Kassim. S. (2009), "Risk Management Practices and Financial Performance of Islamic Banks Malaysian Evidence". 8th International Conference on Islamic Economics and Finance.

Athanasoglou, PP, Brissimis, SN and Delis, MD 2005, "Bank-specific, industry specific and macroeconomics determinants of bank profitability", Bank of Greece, Working Paper, No. 25

Akkizidis, I., \& Khandelwal, S. (2007). "Financial risk management for Islamic banking and finance". Springer.

Abreu, M and Mendes, V 2002, "Commercial Bank Interest Margins and Profitability: Evidence for Some E.U. Countries", University of Porto Working Paper Series, No. 122.

Amin, M. A. M., Sanusi, N. A., Kusairi, S., \& Abdallah, Z. M. (2014). "Inverse relationship of financial risk and performance in commercial banks in Tanzania". Investment Management and Financial Innovations, 11(4), 279-291.

Basel Committee on Banking Supervision (2001). "The New Capital Accord. Bank for International Settlement".

Brezeanu, P., Al Essawi, M. S., Poanta, D., \& Badea, L. (2011). "Does Corporate Governance Impact Risk Management System?”. Theoretical \& Applied Economics, 18(4).

Bikker, J. A., \& Metzemakers, P. A. (2005). "Bank provisioning behaviour and procyclicality". Journal of international financial markets, institutions and money, 15(2), 141-157.

Chaudhry, S.M., \& Kamal, S. (2001). "Introduction to statistical theory part II". Ilmi Katab Khana, Urdu Bazar, Lahore Pakistan.

Demirgnuc- Kunt, A, and Huizinga, H 1999, "Determinants of commercial bank interest margins and profitability some international evidence”, World Bank Economic Review Vol.13, pp. 379-408.

Fakhrunnas, F., \& Imron, M. A. (2019). "Assessing Financial Risk and Regional Macroeconomic Influence to Islamic Rural Bank Performance”. Global Review of Islamic Economics and Business, 7(1), 049-055.

Framework, A. N. C. A. (1999). "Basel Committee on Banking Supervision”. Bank for International Settlements, June.

Hassan, A. (2009). "Risk management practices of Islamic banks of Brunei Darussalam”. The Journal of Risk Finance.

Jorion, Phillipe (2001), "Value at Risk, The New Benchmark for Managing Financial Risk”, McGraw Hill, New York 
Krugman, P. (2009). "The Return of Depression Economics and the Crisis of 2008".

Muhammad, M. B. (2019). "Corporate Governance and Bank Performance: Conventional vs Islamic Banks in Malaysia" (Doctoral dissertation, UTAR).

Markovitz, H. M. (1959). "Portfolio selection: Efficient diversification of investments". John Wiley.

Ostle, B., \& Malone, L. C. (1988). "Solutions Manual for Statistics in Research". Iowa State University Press.

Pasiouras, F and Kosmidou, K 2007, "Factors influencing the profitability of domestic and foreign commercial banks in the European Union", Research in International Business and Finance, Vol. 21, No. 2, pp. 222-237.

Philippe, J. O. R. I. O. N., \& Joseph, K. S. (1996). "Financial Risk Management, Domestic and International Dimensions". Blackwell Business.

Rashid, A., \& Jabeen, S. (2016). "Analyzing performance determinants: Conventional versus Islamic banks in Pakistan". Borsa Istanbul Review, 16(2), 92-107.

Rehman, A. A., Benamraoui, A., \& Dad, A. M. (2018). "A comparative study of Islamic and conventional banks' risk management practices: empirical evidence from Pakistan". Journal of Banking Regulation, 19(3), 222-235.

Ruziqa, A. (2013). "The impact of credit and liquidity risk on bank financial performance: the case of Indonesian Conventional Bank with total asset above 10 trillion Rupiah". International Journal of Economic Policy in Emerging Economies, 6(2), 93-106.

Ross, S. A., Westerfield, R., \& Jordan, B. D. (2008). "Fundamentals of corporate finance". Tata McGraw-Hill Education.

Srairi, S. (2019). "Transparency and bank risk-taking in GCC Islamic banking”. Borsa Istanbul Review, 19, S64S74.

State Bank of Pakistan, https://www.sbp.org.pk/ibd/bulletin/2020/Mar.pdf

Shafiq A. and Nasr M. (2010). "Risk Management Practices Followed By the Commercial Banks in Pakistan". International Review of Business Research Papers Vol. 6. No. 2. Pp. 308- 325.

Suka, J. N. (2011). "The impact of capital adequacy on the financial performance of commercial banks quoted at the Nairobi Stock Exchange" (Doctoral dissertation, University of Nairobi).

Taqi, Usmani Mufti Muhammad. "An Introduction to Islamic Finance, ldaratul Maarif." Karachi, Pakistan (2000).

Toutou, J., \& Xiaodong, X. (2011). The relationship between liquidity risk and performance: An empirical study of banks in Europe 2005-2010

Van Horne, J.C. and Wachowicz J.M. (2005). Fundamentals of Financial Management,12th Edition,Prentice Hall Publishers, New York.

Voinea, Gheorghe, and Sorin Gabriel Anton. "Lessons from the current financial crisis. a risk management approach." Review of Economic and Business Studies 3, no. 1 (2009): 139-147.

Wanjohi, S. M., Wanjohi, J. G., \& Ndambiri, J. M. (2017). "The effect of financial risk management on the financial performance of commercial banks in Kenya". International Journal of Finance and Banking Research, 3(5), 70-81.

Weil J. (2012). “The EU Smiled While Spain's Banks Cooked the Books”. Bloomberg.

Yazid, A. S., Hussin, M. R., \& Daud, W. N. W. (2011). "An examination of enterprise risk management (ERM) practices among the government-linked companies (GLCs) in Malaysia". International Business Research, 4(4), 94.

Zakaria, S., \& Islam, S. (2019). "Financial Risk Management in Banking: Evidence from Asia Pacifi”c (Vol. 17). Routledge.

Zeitun, R. (2012). Determinants of Islamic and conventional banks performance in GCC countries using panel data analysis. Global Economy and Finance Journal, 5(1), 53-72. 